Primljen / Received: 24.6.2016. Ispravljen / Corrected: 28.1.2017.

Prihvaćen / Accepted: 28.2.2017. Dostupno online / Available online: 10.8.2017.

\section{Numerical analysis of RC wall with opening strengthened by CFRP subjected to eccentric loads}

Authors:

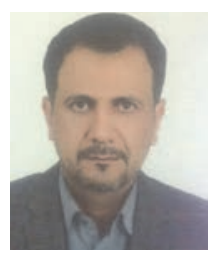

Hussam K. Risan, PhD. CE

AL-Nahrain University

College of Engineering

Department of Civil Engineering

Baghdad, Iraq

dr.hussamrisan@gmail.com

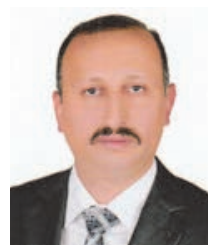

Ibrahim S. I. Harba, PhD. CE

AL-Nahrain University

College of Engineering

Department of Civil Engineering

Baghdad, Iraq

ibraharba@yahoo.com

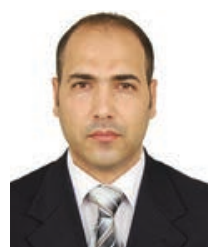

Abdulkhalik J. Abdulridha, PhD. CE

AL-Nahrain University

College of Engineering

Department of Civil Engineering

Baghdad, Iraq

abdulkalikjabbar@yahoo.com

\section{Hussam K. Risan, Ibrahim S. I. Harba, Abdulkhalik J. Abdulridha}

Subject review

\section{Numerical analysis of RC wall with opening strengthened by CFRP subjected to eccentric loads}

Numerical analysis of the central hole in RC walls with and without CFRP, subjected to uniform eccentric vertical line load, is presented in this paper. Six half-scale wall panels were modelled using the ABAQUS software to estimate the strengthening effects. The analysis revealed that the load capacity of the wall in terms of maximum load carrying capacity is influenced by CFRP thickness. It was found that the variation of CFRP thickness greatly influences the ultimate load carrying capacity, crack patterns, principal plastic strain of concrete, and equivalent stress.

Key words:

RC wall with opening, CFRP, plastic damage (cracking) model for concrete

Pregledni rad

Hussam K. Risan, Ibrahim S. I. Harba, Abdulkhalik J. Abdulridha

Numerička analiza ab zida s otvorom ojačanim CFRP-om podvrgnutim ekscentričnim opterećenjima

U radu je provedeno numeričko ispitivanje središnjeg otvora u ab zidovima s CFRP ojačanjem i bez njega podvrgnutim ekscentričnom vertikalnom opterećenju s linearnim prirastom. Šest zidnih ploča u mjerilu $1: 2$ modelirane su u računalnom programu ABAQUS u svrhu procjene učinka ojačanja. Analiza je pokazala da na nosivost zida u smislu maksimalnog opterećenja utječe debljina CFRP-a. Utvrđeno je da varijacija debljine CFRP-a ima značajan utjecaj na krajnju nosivost, pojavu pukotina, glavnu plastičnu deformaciju betona i ekvivalentno naprezanje.

Ključne riječi:

zid nosiv u dva smjera, ab zid s otvorom, CFRP, model plastičnoga popuštanja (raspucavanja) betona

Übersichtsarbeit

Hussam K. Risan, Ibrahim S. I. Harba, Abdulkhalik J. Abdulridha

Nummerische Analyse einer Stahlbetonwand mit einer CFRP-verstärkten Öffnung, die exzentrischen Belastungen ausgesetzt wird

In der Abhandlung wurde eine nummerische Untersuchung der mittleren Öffnung in Stahlbetonwänden mit und ohne CFRP-Verstärkung durchgeführt, die einer exzentrischen vertikalen Belastung mit linearer Verstärkung unterzogen wurden. Sechs Wandplatten in einem Maßstab $1: 2$ wurden im Computerprogramm ABAQUS zum Zwecke der Einschätzung der Verstärkungswirkung modelliert. Die Analyse zeigte, dass die Tragähigkeit der Wand im Sinne der maximalen Belastung die Stärke des CFRP beeinflusst. Festgestellt wurde, dass die Variation der Stärke des CFRP wesentlichen Einfluss auf die endgültige Tragfähigkeit, das Auftreten von Rissen, die plastische Hauptverformung des Betons und die Vergleichsspannung hat.

Stahlbetonwand mit Öffnung, CFRP, Modell der plastischen Abspannung (Rissbildung) des Betons 


\section{Introduction}

Wall panels are important structural members that can resist lateral loads due to high in-plane stiffness. Design considerations for any structure commonly result in RC walls with openings. In general, discontinuity regions in walls due to openings can be a source of stress concentration, which cannot be classified as identified patterns that make the design so complicated [1-3]. By reason of higher capability of stress redistribution in $\mathrm{RC}$ walls, a small opening has a small effect on general behaviour of the wall. Conversely, large openings lead to significant reduction in both stiffness and rigidity of walls [4]. Recently, CFRP is increasingly being used as a means to increase strength of the existing RC structures because of its excellent characteristics such as the ease of installation, high resistance, high strength to weight ratio, and durability $[5,6]$. The American Concrete Institute code ACI 318M-14 [7] considers only RC bearing walls supported at the top and bottom (one way action). On the other hand, the Australian Code AS3600-2009 [8] includes the side restraint effects. These code requirements do not include the effects on carrying load capacity caused by restraints in three and four side edges of walls. They are also limited to RC walls with the slenderness ratios of less than 30 and to RC walls without openings.

In the past decade, CFRP was used for strengthening columns and beams with regard to bending, shear and twisting. Today, due to high strength and small weight of CFRP, its simple installation and high corrosion resistance, the use of CFRP attached to the RC wall panels with openings is also becoming popular, since CFRP helps in preventing brittle failure and reducing crack formation in hole corners. In 1999, Lombard et al [9] studied validity of fibre sheet strengthening of RC shear walls by testing four walls under quasi-static cyclic load sequence with CFRP configuration. The strengthened system consisted of fibre sheets on both faces of the walls in one or two directions. According to the experimental values recorded, they developed a theoretical model to determine the ultimate flexural capacity of strengthened or repaired walls and plain RC shear walls with externally bonded CFRP. In 2000, Sugiyama et al [10], studied seismic performance of eight RC walls with openings strengthened using FRP sheets, which are classified as nonstructural members. They concluded that even if the maximum load carrying capacity of walls is increased, the overall behaviour would remain the same. In 2003, Antoniades and Kappos [11] studied the method for strengthening RC walls with a low slenderness ratio. The walls were designed according to $\mathrm{ACl}$ code requirements. In this study, the walls were tested by subjecting them, in the first step, to cyclic load until failure. In the second step, the tested walls were repaired and then strengthened using fibre-reinforced polymer jackets. The results proved that the strength of wall increases from 2 to 32 percent if fibre-sheet anchorage techniques are used. In 2005, Li et al. [12] studied accuracy of a numerical method in predicting performance of shear members strengthened with GFRP in one-way action only. In this study, the model based on damaged plasticity was used to model the concrete performance under repeated loading and the deformation compatibility. Due to fibre reinforced polymer, a SPRING element was used. The comparison between computational and experimental results showed that the behaviour of fibre-strip strengthening of RC shear members can be predicted using the finite element method.

A comprehensive study of behaviour of solid shear members in both one and two-way deflection, with the slenderness ratios between 25 and 40, was made in 2002 by Doh et al. [13] and in 2005 by Doh and Fragomeni [14]. A design formula was also derived in the scope of this study. The study was followed by test report on 12 half-scale RC wall panels with openings. Therefore, this paper reports on the experimental setup, typical crack patterns, failure loads, and load deflection characteristics. In 2013, Mohammed and Ean studied behaviour of singledeflection RC shear members with openings strengthened with CFRP. In the scope of this study, they tested wall panels subjected to uniform axial eccentric load. Two types of CFRP application modes were used (alongside the opening and at an angle of $45^{\circ}$ to the opening). They noticed that the maximum strength of RC wall increases when CFRP is used. They also predicted an empirical equation. In 2014, Lima et al [1] studied behaviour of a RC wall with opening. They tested six half-scaled wall panels with the slenderness ratio of 30. The panels, supported on two and three sides, were strengthened with two types of CFRP arrangements around opening and subjected to uniform axial eccentric load. They found that CFRP increases the ultimate load capacity of the walls under various load conditions. This research represents the first investigation of the use of CFRP for strengthening RC walls with high slenderness ratio and with three side restraints.

Additional research is nevertheless necessary to determine structural performance of RC walls with holes strengthened by CFRP under different boundary conditions. Also, most of the earlier investigations only discussed experimental studies without conducting three-dimension nonlinear numerical analysis and modelling. Therefore, the influence of CFRP on the behaviour of RC walls with holes under eccentric uniform line load is studied in this paper by using computational analysis based on ABAQUS software. In this research, the numerical model is verified using experimental data provided by Lima et al [1]. After that, the effects of CFRP thickness are studied.

\section{Overview of experimental program}

The experimentally tested RC wall panel with openings, with and without CFRP, presented by Lima et al [1], was used in this study to calibrate FEM results and verify its application. Six RC (half scaled) walls panels with $14 \%$ identical openings, supported at two and three sides, were tested. The aspect ratio $(\mathrm{H} / \mathrm{L})$, slenderness ratio $\left(\mathrm{H} / \mathrm{t}_{\mathrm{w}}\right)$, and thickness ratio $\left(\mathrm{L} / \mathrm{t}_{\mathrm{w}}\right)$ of all wall panels amounted to 1 , 30, and 30, respectively. The walls were designed as follows:

1. W1-TO, one way buckling with two side supports without CFRP

2. W2-T1, one way buckling with two side supports with CFRP sheets diagonal to the opening

3. W3-T1, one way buckling with two side supports with CFRP alongside the opening 
4. W4-TO, two way buckling with three side supports

5. W5-T1, two way buckling with three side supports with CFRP sheets diagonal to the opening

6. W6-T1, two way buckling with three side supports with CFRP alongside the opening.

All wall panels were subjected to uniform axial load at the eccentricity of $\left(t_{w} / 6\right)$ and tested until failure. The crack pattern and ultimate load capacity were recorded. Reinforcement ratios were the same for all wall specimens $(4 \mathrm{~mm}$ diameter, 100 $\mathrm{mm}$ spacing and $\mathrm{f}_{\mathrm{y}}=450 \mathrm{MPa}$ ) in both directions, and placed centrally in the panel cross section. Also the reinforcement ratio was compliant with minimum standard requirements. The CFRP prosperities and dimensions are listed in Tables 1 and 2. Figures 1 and 2 also show specimen details and CFRP layout.

Table 1. Prosperity of CFRP: Sika Wrap- $23^{\circ} \mathrm{C}$ [1]

\begin{tabular}{|c|c|c|c|c|c|}
\hline $\begin{array}{c}\text { Areal } \\
\text { weight } \\
{\left[\mathrm{g} / \mathrm{m}^{2}\right]}\end{array}$ & $\begin{array}{c}\text { Thickness } \\
{[\mathrm{mm}]}\end{array}$ & $\begin{array}{c}\text { Density } \\
{\left[\mathrm{g} / \mathrm{cm}^{3}\right]}\end{array}$ & $\begin{array}{c}\text { Tensile } \\
\text { modulus } \\
{\left[\mathrm{N} / \mathrm{mm}^{2}\right]}\end{array}$ & $\begin{array}{c}\text { Tensile } \\
\text { strength } \\
{\left[\mathrm{N} / \mathrm{mm}^{2}\right]}\end{array}$ & $\begin{array}{c}\text { Elongation } \\
\text { at failure } \\
{[\%]}\end{array}$ \\
\hline 230 & 0.128 & 1.8 & 234000 & 4300 & 1.8 \\
\hline
\end{tabular}

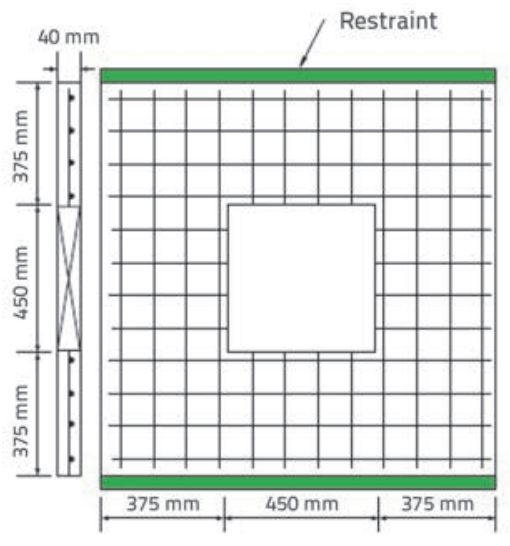

W1 - T0

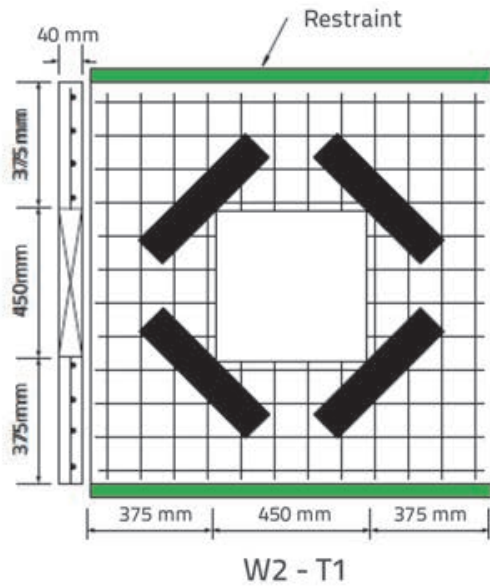

W2 - T1
Table 2. Dimensions of the applied CFRP sheet [1]

\begin{tabular}{|c|c|c|c|}
\hline $\begin{array}{c}\text { Length of } \\
\text { opening } \\
{[\mathrm{mm}]}\end{array}$ & $\begin{array}{c}\text { Width of } \\
\text { opening } \\
{[\mathrm{mm}]}\end{array}$ & $\begin{array}{c}\text { Width of } \\
\text { CFRP } \\
{[\mathrm{mm}]}\end{array}$ & $\begin{array}{c}\text { Length of } \\
\text { CFRP } \\
{[\mathrm{mm}]}\end{array}$ \\
\hline 450 & 450 & 105 & 770 and 450 \\
\hline
\end{tabular}

\section{Method and materials}

A nonlinear computational analysis based on the finite element ABAQUS software was performed in this research. The C3D4R (4-node linear tetrahedron three-dimensional) solid elements with three degrees of freedom in each node were used in the RC wall modelling. In case of three dimensional concrete elements, there are two methods for bar reinforcement modelling by means of ABAQUS software. Reinforcement bars can be modelled as either rebar layers or truss elements. A discrete reinforcement representation in the form of two dimensional truss elements (T3D2), which are embedded in concrete solid elements, was used in this study [16]. The CFRP strip is represented with 4-node shell elements. It should be noted that Selected Model Parameters are used in ABAQUS to carry out the analysis (dilation angle,

Figure 1. RC wall panels in one way action and CFRP layout [1]
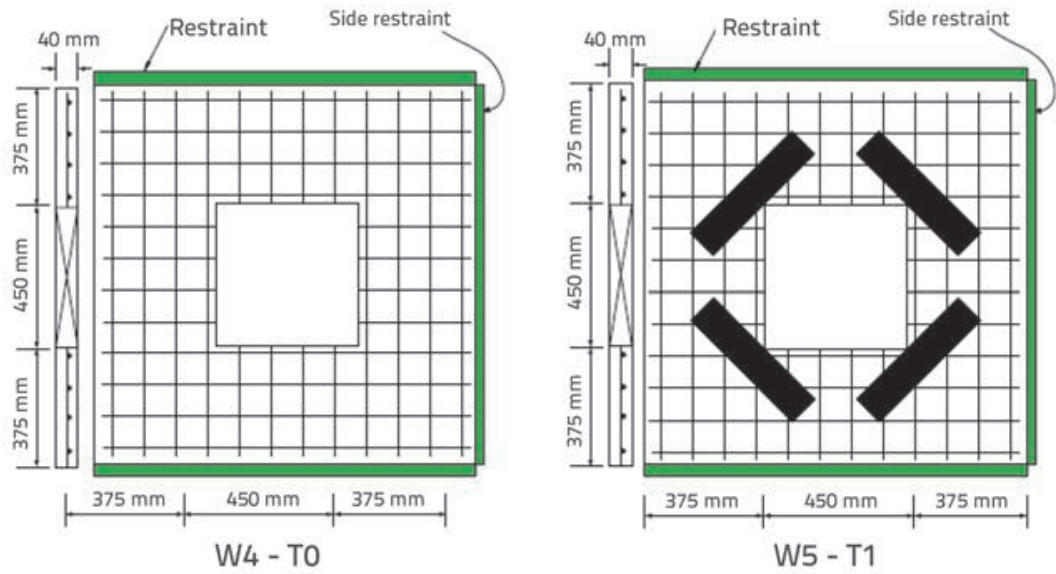

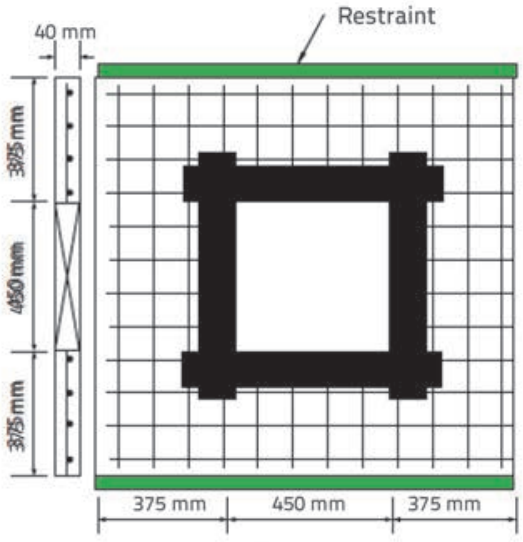

W3 - T1

Figure 2. RC wall panels with three sided restraint and CFRP layout [1]

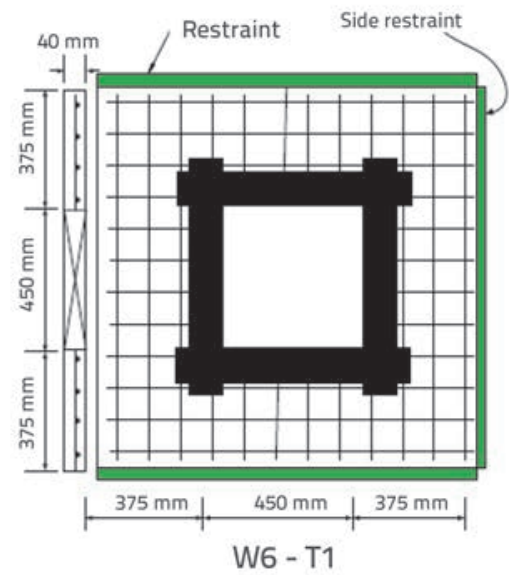



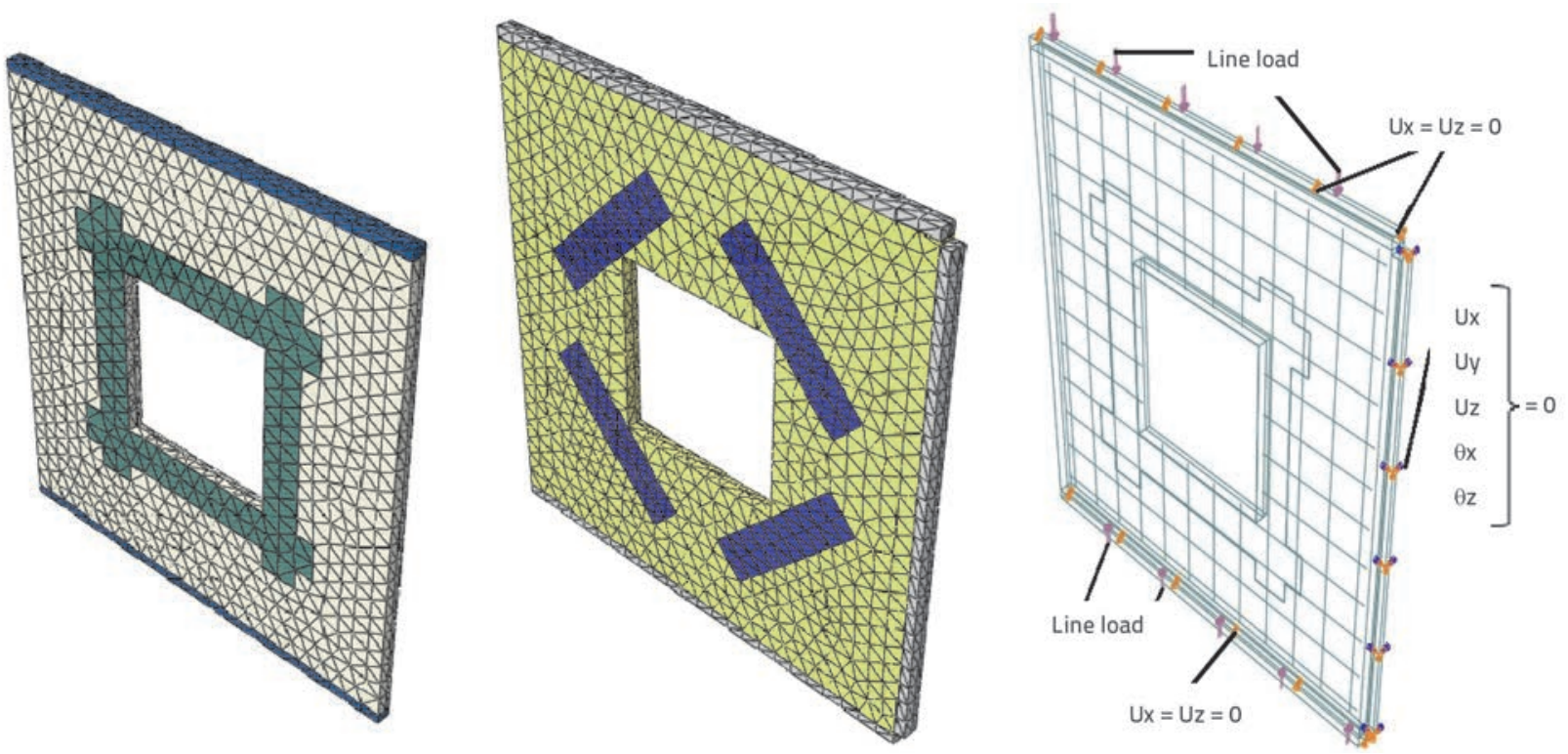

Figure 3. Finite element mesh, loads and boundary conditions

$\psi=33$, compressive strain at peak $\varepsilon_{c}=0.0002$, inelastic strain of concrete in compression, $\varepsilon_{c}^{\text {in }}=0.00082$ to 0.0033 , cracking strain of concrete in tension $\varepsilon_{\mathrm{t}}^{\mathrm{ck}}=0.0002$, and default data incorporated in ABAQUS are used as input data for plasticity damage model in concrete). The boundary condition of the RC wall at base was simulated as an eccentric pin end to allow rotation, and roller supports were placed at the side of the top wall end to allow for vertical movement and rotation. Furthermore, an eccentric vertical uniform line load was applied on top of the wall in order to simulate the experimental loading status. Figure 3 shows the finite element model, loads, and boundary conditions.

Steel is defined as an elastic - perfectly plastic material, while CFRP is defined as a linear elastic material. Concrete is modelled by means of a Concrete Damage Plasticity (CDP) value. This model was initially developed by Lubliner et al. [17] and improved by Lee $\&$ Fenves [18]. In this model, the yield surface progress development is controlled by two strain-hardening variables (Habbit et. al. [19]). The concrete stress-strain curve data in compression are adopted in the present study based on the Hognestad equation [20, 21]. A perfect bond between concrete and CFRP is adopted in the study [22].

\section{Results and discussion}

The validity and efficiency of numerical results for the proposed material behaviour of concrete, steel and CFRP will be checked with experimental results in this section. In addition, verifications will be made by comparing the numerical crack patterns, concrete plastic strain, and load carrying capacity with experimental tests data by Lima et al [1].

Table 3 shows ultimate load capacity results for the experimental and numerical analysis. It can be noted that the average numerical ultimate loads exceeded experimental ultimate load by $0.533 \%$ (Num. Load/Exp. Load) for one way panels. The average numerical ultimate loads were exceeded by $2.8 \%$ by experimental ultimate load for two-way panels.

Figures 4 and 5 show experimental and numerical crack patterns and concrete plastic strain in one-way and twoway deflections, respectively. In Figure 4, the observed crack patterns for experimental and FE analysis were horizontal on the flexural tension faces (perpendicular to the direction of load) with failure happening approximately in the middle of the wall, signifying that the bending failure occurred in one-way action. On the other hand, as shown in Figure 5, the cracking

Table 3. Experimental and numerical ultimate loads

\begin{tabular}{|c|c|c|c|c|c|}
\hline Panel designation & CFRP type & $\begin{array}{c}\text { CFRP thickness } \\
{[\mathrm{mm}]}\end{array}$ & Constraint type & $\begin{array}{c}\text { Experimental } \\
\text { analysis } \\
{[\mathrm{kN}]}\end{array}$ & $\begin{array}{c}\text { Numerical } \\
\text { analysis } \\
{[\mathrm{kN}]}\end{array}$ \\
\hline W1-T0 & - & - & 2-Sides & 273.9 & 278.2 \\
\hline W2-T1 & Inclined 45 & 0.128 & 2-Sides & 315.2 & 314.9 \\
\hline W3-T1 & Around 90 & 0.128 & 2-Sides & 348.5 & 349.3 \\
\hline W4-T0 & - & - & 3-Sides & 450.0 & 448.2 \\
\hline W5-T1 & Inclined 45 & 0.128 & 3-Sides & 699.0 & 682.7 \\
\hline W6-T1 & Around 90 & 0.128 & 3-Sides & 660.6 & 661.2 \\
\hline
\end{tabular}


patterns developed in a two-way biaxial deflection manner. Cracks were also observed at the corners of the wall panels. The cracking configuration in the numerical model agrees well with experimental data. The above discussion suggests that both cracking patterns and ultimate load capacity results are in good agreement, and so the simulation results using the proposed numerical analysis method are considered to be reliable.

The variation in CFRP thickness from $0.128 \mathrm{~mm}$ to $0.256,0.348$ and $0.512 \mathrm{~mm}$ to study the influence of CFRP strengthening on the failure behaviour of RC wall with openings was conducted in terms of ultimate load carrying capacity, crack pattern, and principal plastic strain. The ultimate load carrying capacity recorded for four CFRP thickness values is presented in Table 4. Based on the observed ultimate load results, it can be stated that the thickness of 0.348 $\mathrm{mm}$ gives higher ultimate load for two CFRP sheet arrangements due to increase in resistance to flexural moment.

Figures 6 to 9 show maximum principal plastic strain of concrete. It is obvious from these figures that general cracking pattern and plastic strain tendencies of concrete were similar for one way and two way actions of the RC wall for CFRP thicknesses ranging from $0.128 \mathrm{~mm}$ to $0.512 \mathrm{~mm}$, with better crack distribution with an increase in CFRP thickness.

Von-Misses describes CFRP with different sheet thicknesses at ultimate load level, as depicted in Figures 10 to 13. These figures clearly show that the solution becomes effective at the critical CFRP thickness, which is equivalent to $0.348 \mathrm{~mm}$. No significant effect on wall capacity can be observed above and below this thickness. The CFRP $0.348 \mathrm{~mm}$ in thickness is the amount of CFRP that is approximately equivalent to the cut-off reinforcing bars in the wall due to opening.
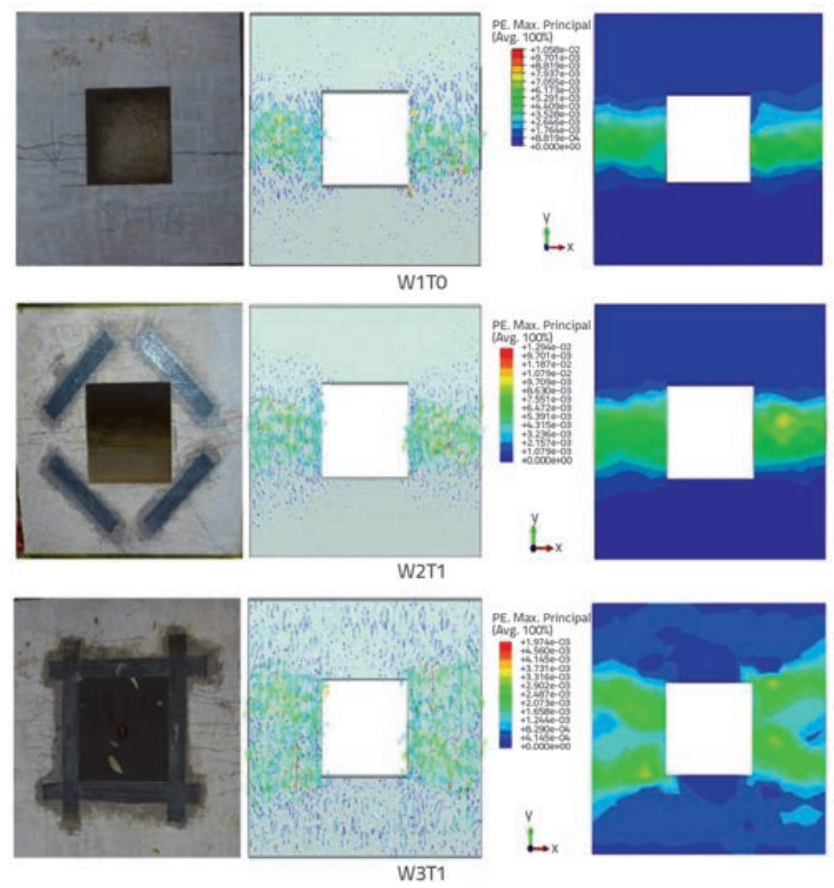

Figure 4. Experimental and numerical crack patterns and concrete plastic strain for one-way action panels
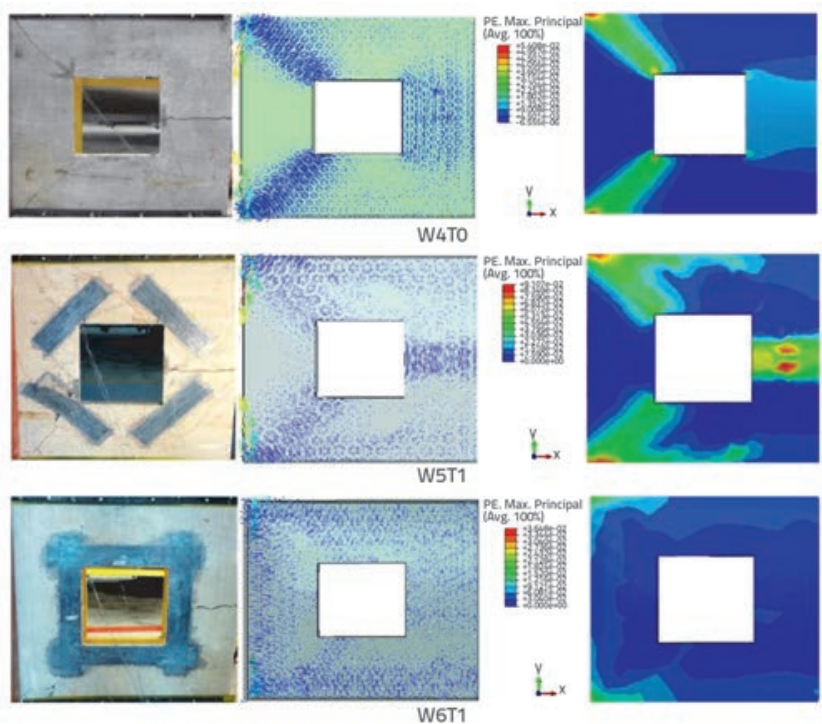

Figure 5. Experimental and numerical crack patterns and concrete plastic strain for two-way action panels

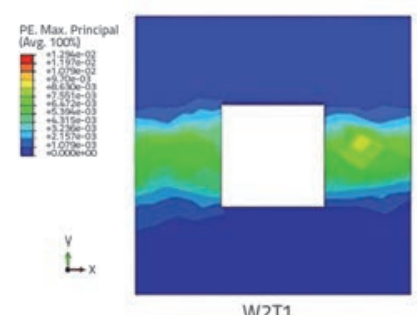

W2T1

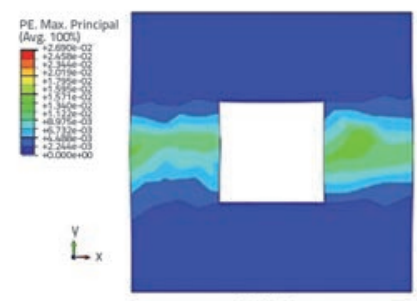

W2T3

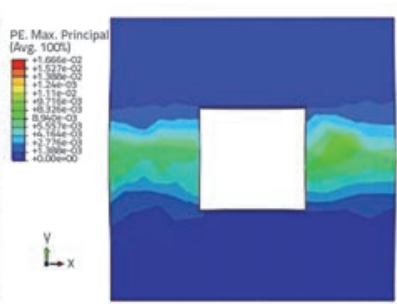

W2T2

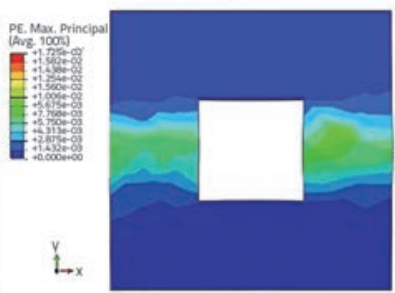

W2TL
Figure 6. Maximum plastic strain for one-way action wall with inclined and different CFRP thicknesses
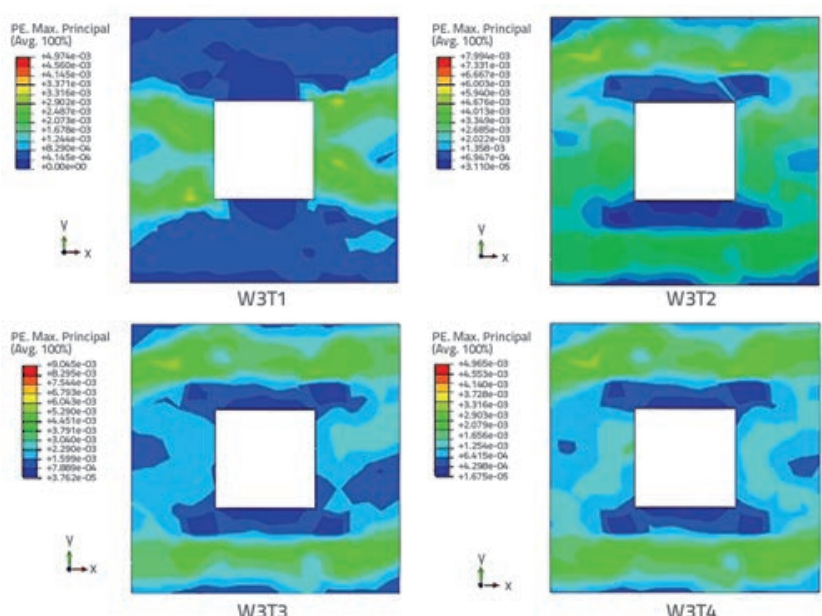

Figure 7. Maximum plastic strain for one-way action wall with around and different CFRP thicknesses 
Table 4. Numerical ultimate loads

\begin{tabular}{|c|c|c|c|c|}
\hline Panel designation & CFRP type & CFRP thickness [mm] & Constraint type & Numerical analysis [kN] \\
\hline W2-T1 & Inclined $45^{\circ}$ & 0.128 & 2-Sides & 314.9 \\
\hline W2-T2 & Inclined $45^{\circ}$ & 0.256 & 2-Sides & 316.7 \\
\hline W2-T3 & Inclined $45^{\circ}$ & 0.348 & 2-Sides & 335.6 \\
\hline W2-T4 & Inclined $45^{\circ}$ & 0.512 & 2-Sides & 314.3 \\
\hline W3-T1 & Around $90^{\circ}$ & 0.128 & 2-Sides & 349.3 \\
\hline W3-T2 & Around $90^{\circ}$ & 0.256 & 2-Sides & 424.4 \\
\hline W3-T3 & Around $90^{\circ}$ & 0.348 & 2-Sides & 433.8 \\
\hline W3-T4 & Around $90^{\circ}$ & 0.512 & 2-Sides & 400.9 \\
\hline W5-T1 & Inclined $45^{\circ}$ & 0.128 & 3-Sides & 682.7 \\
\hline W5-T2 & Inclined $45^{\circ}$ & 0.256 & 3-Sides & 831.1 \\
\hline W5-T3 & Inclined $45^{\circ}$ & 0.348 & 3-Sides & 832.7 \\
\hline W5-T4 & Inclined $45^{\circ}$ & 0.512 & 3-Sides & 722.8 \\
\hline W6-T1 & Around $90^{\circ}$ & 0.128 & 3-Sides & 661.2 \\
\hline W6-T2 & Around $90^{\circ}$ & 0.256 & 3-Sides & 746.9 \\
\hline W6-T3 & Around $90^{\circ}$ & 0.348 & 3-Sides & 826.2 \\
\hline W6-T4 & Around $90^{\circ}$ & 0.512 & 3-Sides & 748.6 \\
\hline
\end{tabular}

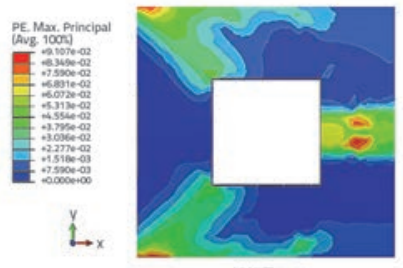

W5T1

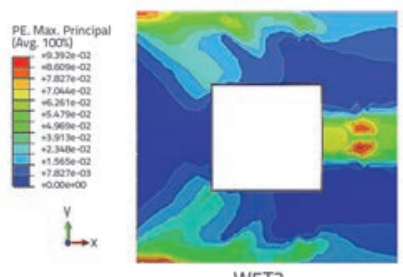

W5T3

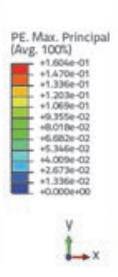

i.

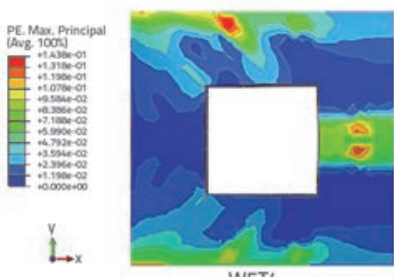

W5T4

Figure 8. Maximum plastic strain for two-way action wall with inclined and different CFRP thicknesses
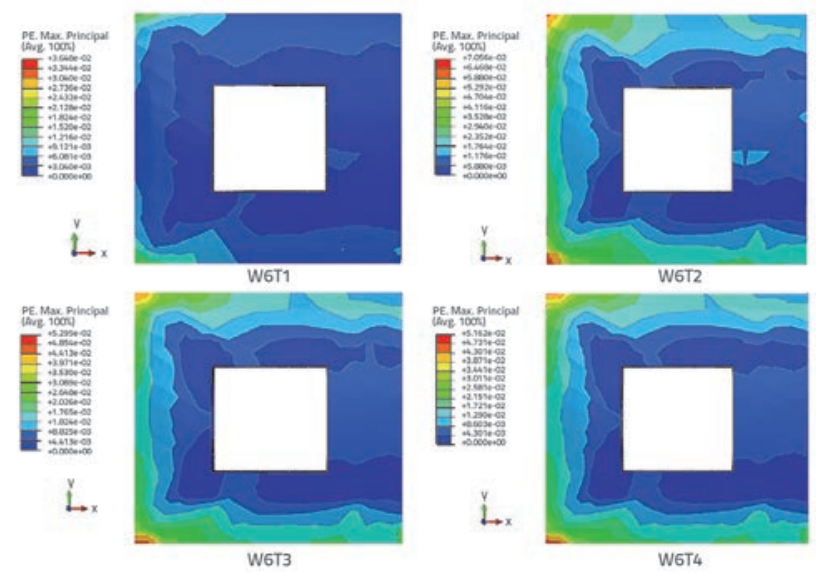

Figure 9. Maximum plastic strain for two-way action wall with around and different CFRP thicknesses

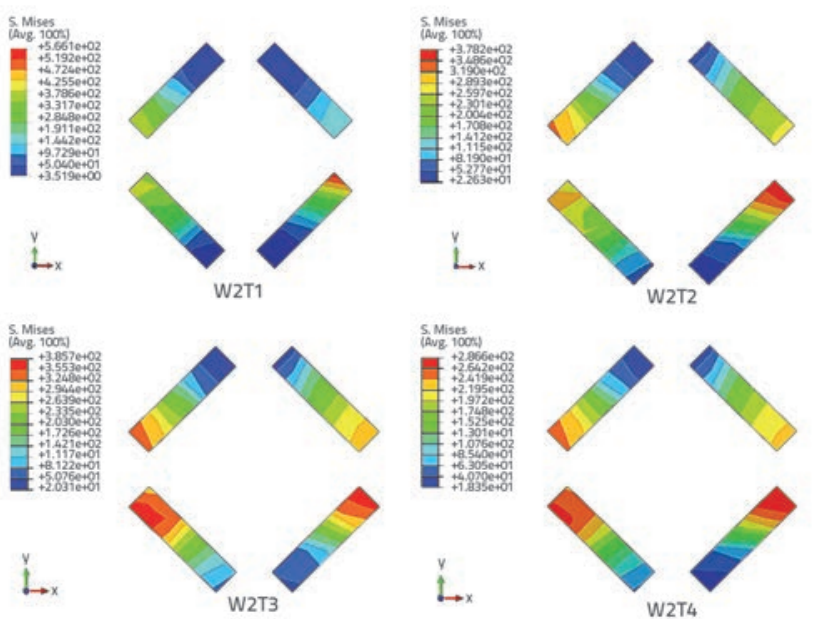

Figure 10. Von-Misses stress for one-way action wall with Inclined and different CFRP thicknesses
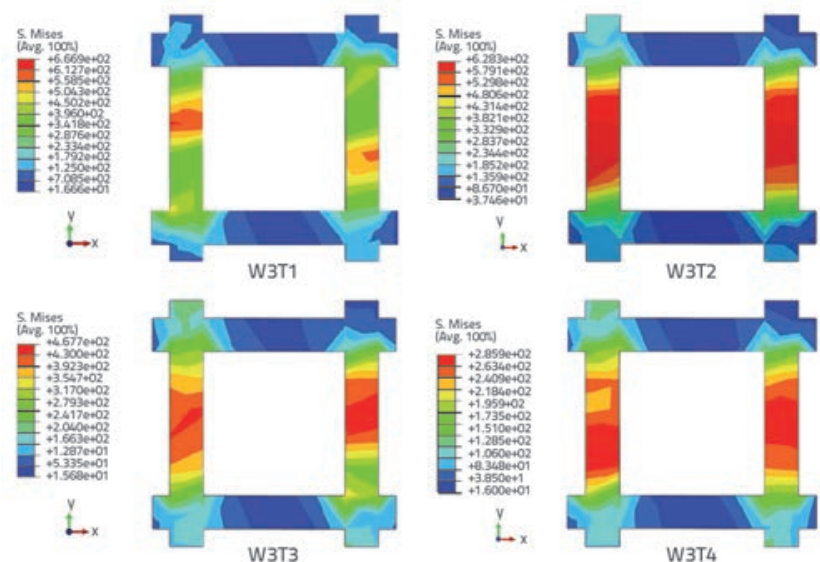

Figure 11. Von-Misses stress for one-way action wall with around and different CFRP thicknesses 


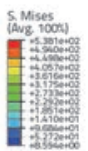

Lx
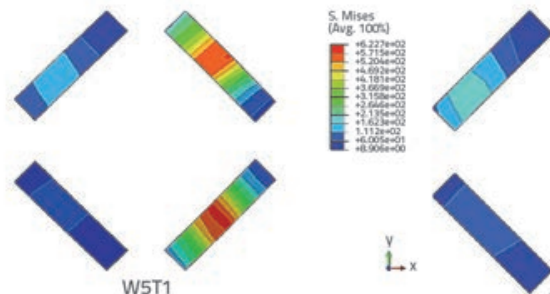

L.

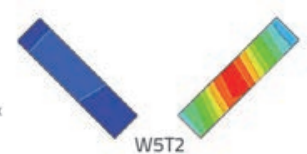

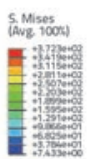

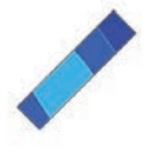

$L_{x}$

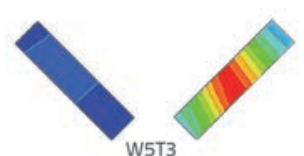

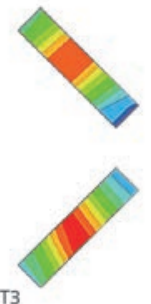

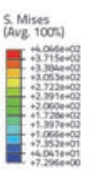

$\stackrel{y}{L}$

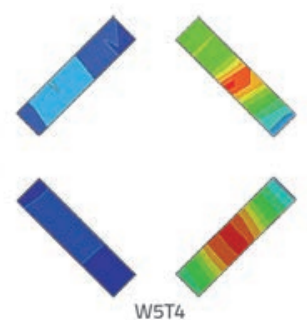

Figure 12. Von-Misses stress for two-way action wall with inclined and different CFRP thicknesses

\section{Conclusion}

The present numerical investigation has two main objectives: to calibrate experimental tests results obtained by Lima et al [1] and to study the effects of increasing CFRP thickness on the behaviour of RC wall with openings, in one-way and twoway action in terms of modes of failure, crack patterns and ultimate load carrying capacity. The following conclusions can be made:

- The comparison between computational results based on plasticity damage model and experimental results, either in terms of ultimate load carrying capacity or crack patterns, indicates that the proposed finite element analysis can give a

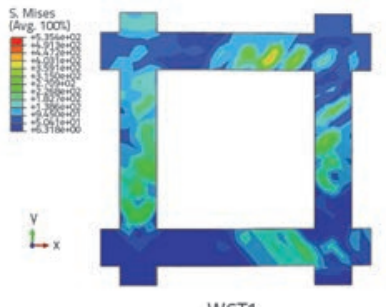

W6T1

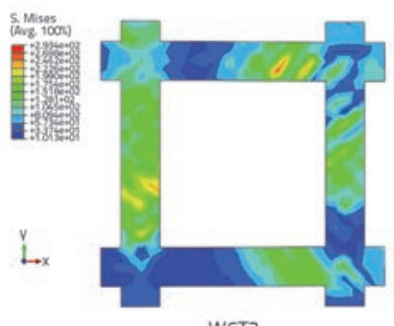

W6T3

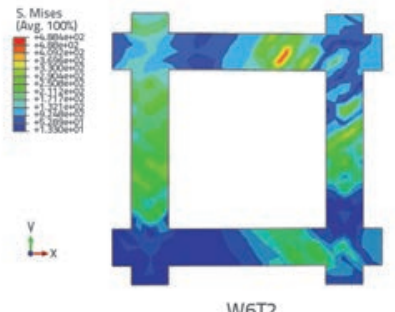

W6T2

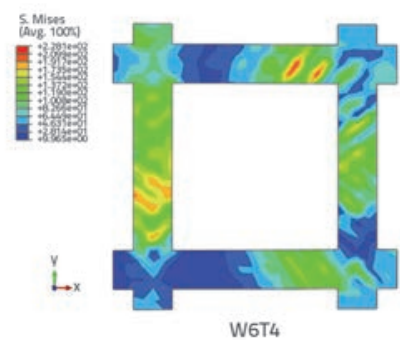

Figure 13. Von-Misses stress for two-way action wall with around and different CFRP thicknesses

very good prediction of behaviour of RC walls with openings and with CFRP strengthening.

- The numerical results show that the variation in CFRP thickness has a significant influence on the ultimate load carrying capacity, crack patterns, concrete principal plastic strain, and equivalent stress in CFRP sheets. When the CFRP thickness increases to $0.348 \mathrm{~mm}$, the ultimate loads increase and enable better crack distribution due to increase in the flexural moment capacity of RC walls. The effect of this increase stabilises around the critical value of CFRP thickness, which is approximately equivalent to the cut-off reinforcing bars in the wall due to opening.

\section{REFERENCES}

[1] Lima, M.M., Doh, J.H., Miller, D.: Experimental Study of RC Walls with Opening Strengthened by CFRP, $23^{\text {rd }}$ Australian Conference on the Mechanics of Structures and Materials (ACMSM23), ed. Smith, S.T., Byron Bay, Australia, 9 - 12 December 2014.

[2] Sas, G.: FRP Shear Strengthening of RC Beams and Walls, Department of Civil, Mining and Environmental Engineering, Lulea University of Technology, Licentiate Thesis, 2008.

[3] Bozdogan, K.B.: A method for free vibration analysis of stiffened multi-bay coupled shear walls, Asian Journal of Civil Engineering, 7 (2006) 6 .

[4] Elnashai, A., Sarno, L.: Fundamentals of Earthquake Engineering, John Wiley, New York, 2008, https://doi. org/10.1002/9780470024867

[5] Bhinia, D., Prakash, V., Pandey, A.D.: A procedure for evaluation of coupling beam characteristics of coupled shear walls, Asian Journal of Civil Engineering, 8 (2007) 3.
[6] Enochsson, O., Lundgvist, J., Taljsten, B., Rusinowski, P., Olofsson, T.: CFRP strengthened openings in two-way concrete slabs: an experimental and numerical study, Construction and Building Materials, 21 (2002) 4.

[7] ACl 318M-14, Building Code Requirements for Structural Concrete, American Concrete Institute, Detroit, USA

[8] AS3600-2009, Concrete Structures, Standards Australia, Sydney, Australia, 2009. Casadei, P., Ibell, T., and Nanni, A. (2003). "Experimental results of one-way slabs with openings strengthened with CFRP laminates." Fibre-reinforced polymer reinforcement for concrete structures FRPRCS6.

[9] Lombard, J.: Seismic Strengthening and Repair of Reinforced Concrete Shear Walls Using Externally Bonded Carbon Fibre Tow Sheets, Department of Civil and Environmental Engineering, Carleton University, Master of Engineering thesis, 1999. (Cited in Ref. 1) 
[10] Sugiyama, T., Uemura, M., Fukuyama, H., Nakano, K., Matsuzaki, Y.: Experimental study on the performance of the RC frame in filled cast-in-place on-structural RC walls retrofitted by using carbon fibre sheets, Proceedings of the $12^{\text {th }}$ World Conference on Earthquake Engineering, New Zealand, Paper No. 2153, 2000.

[11] Antoniades, K.K., Salonikios, T.N., Kappos, A.J.: Cyclic tests on seismically damaged reinforced concrete walls strengthened using fibre -reinforced polymer reinforcement, ACl Structural Journal, 100 (2003) 4.

[12] Li, Z.J., Balendra, K.H., Tan, K.H.: Finite Element Modeling of Cyclic Behaviour of Shear Wall Structure Retrofitted Using GFRP, ACI-SP, 2005.

[13] Doh, J.H., Fragomeni, S., Loo, Y.C.: Evaluation of experimental behaviour of normal and high strength reinforced concrete walls in two-way action, Proceedings of the $17^{\text {th }}$ Advanced in Mechanics of Structures and Materials, Gold Coast, Australia, June, (2002).

[14] Doh, J.H.. Fragomeni, S.: Evaluation of experimental work on concrete walls in one and two-way action, Australian Journal of Structural Engineering, 6 (2005) 1.

[15] Mohammed, B.S., Ean Malek, L.: One way RC wall panels with openings Strengthened with CFRP, construction and building materials
[16] Kwak, H.G., Kim, D.Y.: Nonlinear analysis of RC shear walls considering tension stiffening effect, Computers and Structures, 79 (2001).

[17] Lubliner, J., Oliver, J., Oller, S., Oñate, E.: A plastic damage model for concrete, Int J Solids Struct, 25 (1989) 3, https://doi. org/10.1016/0020-7683(89)90050-4

[18] Lee, J., Fenves, G.L.:"Plastic-damage model for cyclic loading of concrete structures, J Eng Mech, 124 (1998) 8, https://doi. org/10.1061/(ASCE)0733-9399(1998)124:8(892)

[19] Hibbitt, Karlsson \& Sorensen Inc., ABAQUS theory manual, user manual and example manual, Version 6.8, Providence, RI, 2008.

[20] Hognestad, E.: A study on combined bending and axial load in reinforced concrete members, University of Illinois Engineering Experiment Station, University of Illinois at Urbana-Champaign, IL, (1951).

[21] Mostofi Nejad, D.: Reinforced Concrete Structures. Vol.1. 14 edition, Esfahan: Arkane Danesh, 2009.

[22] ACl Committee 440.2R 2002., Guide for the Design and Construction of Externally Bonded FRP Systems for Strengthening Concrete Structures. 